\title{
Orchiectomy Performed in Two Patients with Brucella Orchitis Mimicking Testicular Tumour \\ V Turhan ${ }^{1}$, A Acar ${ }^{1}$, F Ateş ${ }^{2}$, H Diktaş ${ }^{1}$, A Haholu $^{3}$, O Öncül ${ }^{1}$, L Görenek $^{1}$
}

\begin{abstract}
Brucellosis is a zoonosis caused by gram negative coccobacilli and it is an endemic infectious disease in Turkey. Infection is usually acquired as a result of direct contact with infected animals or by consuming milk or cheese freshly made from them. There exists a wide spectrum of clinical signs and symptoms in brucellosis. Many systems including musculoskeletal, gastrointestinal, cardiovascular and genitourinary may be involved in brucellosis. The genitourinary system is affected in $2 \%$ to $20 \%$ of the cases with brucellosis. The most common forms of brucellosis are epididymo-orchitis, testicular abscess and atrophy. The serum agglutination test to detect the presence of antibodies is a reliable test in patients with urogenital symptoms. Long-term and combined antibacterial therapy have been found to be effective in brucellosis. We present two cases undergoing orchiectomy because of testicular mass before the diagnosis of brucellosis was made.
\end{abstract}

Keywords: Abscess, brucellosis, orchiectomy, urogenital system

\section{Orquiectomía Realizada en Dos Pacientes con Orquitis Brucelosa Semejante a un Tumor Testicular

\author{
V Turhan ${ }^{1}$, A Acar ${ }^{1}$, F Ateş², H Diktaş ${ }^{1}$, A Haholu ${ }^{3}$, O Öncül ${ }^{1}$, L Görenek $^{1}$
}

\begin{abstract}
RESUMEN
La brucelosis es una zoonosis causada por cocobacilos gram negativos, y es una enfermedad infecciosa endémica en Turquía. La infección generalmente se adquiere como resultado del contacto directo con animales infectados o por consumo de leche o queso recién producidos a partir de ellos. Existe un amplio espectro de signos y síntomas clínicos de la brucelosis. Muchos sistemas, incluyendo los sistemas musculoesquelético, cardiovascular, gastrointestinal y génitourinario, pueden estar implicados en la brucelosis. El sistema génitourinario se ve afectado en $2 \%$ a $20 \%$ de los casos con brucelosis. Las formas más comunes de brucelosis son la epidídimo-orquitis, el absceso testicular, y la atrofia. La prueba de aglutinación de suero para detectar la presencia de anticuerpos es una prueba confiable en pacientes con sintomas urogenitales. Se ha hallado que la terapia antibacteriana combinada y a largo plazo son eficaces en la brucelosis. Presentamos dos casos sometidos a orquiectomía debido a una masa testicular antes de que se realizara el diagnóstico de brucelosis.
\end{abstract}

Palabras claves: Absceso, brucelosis, orquiectomía, sistema urogenital

West Indian Med J 2013; 62 (6): 557

From: ${ }^{1}$ Department of Infectious Diseases and Clinical Microbiology, ${ }^{2}$ Department of Urology, and ${ }^{3}$ Department of Pathology, GATA Haydarpasa Training Hospital, Istanbul, Turkey.

Correspondence: Dr H Diktas, Gulhane Millitary Medical Academy (GATA) Haydarpasa Training Hospital, Department of Infectious Diseases and Clinical Microbiology, 34668 Uskudar, Istanbul, Turkey. Fax: +90 216348 78 80, e-mail: hd3207@gmail.com

\section{INTRODUCTION}

Brucellosis is a zoonotic disease caused by gram negative coccobacilli. It is endemic in Turkey and can involve multiple organs and systems. Genitourinary involvement of brucellosis may manifest as prostatitis, epididymo-orchitis, cystitis, pyelonephritis, interstitial nephritis or renal abscess. The epididymis seems to be the most commonly affected 
organ of the genitalia and lower urinary tract. Epididymitis due to Brucella can cause serious complications, such as necrotizing orchitis, testicular abscess and mass if left untreated (1). Here, we report two cases with brucellosis undergoing orchiectomy because of a testicular mass suspected of being a neoplasia.

\section{CASE REPORTS}

Case 1: A 23-year old dairyman was admitted to a tertiary care hospital with complaints of painful left testicular mass, fever and malaise. Physical examination revealed that the left hemiscrotum was tender and enlarged. He underwent left radical inguinal orchiectomy with suspicion of testicular tumour. Pathological diagnosis was reported as 'granulomatous orchitis' (Figs. 1 and 2). Thereafter, the patient was

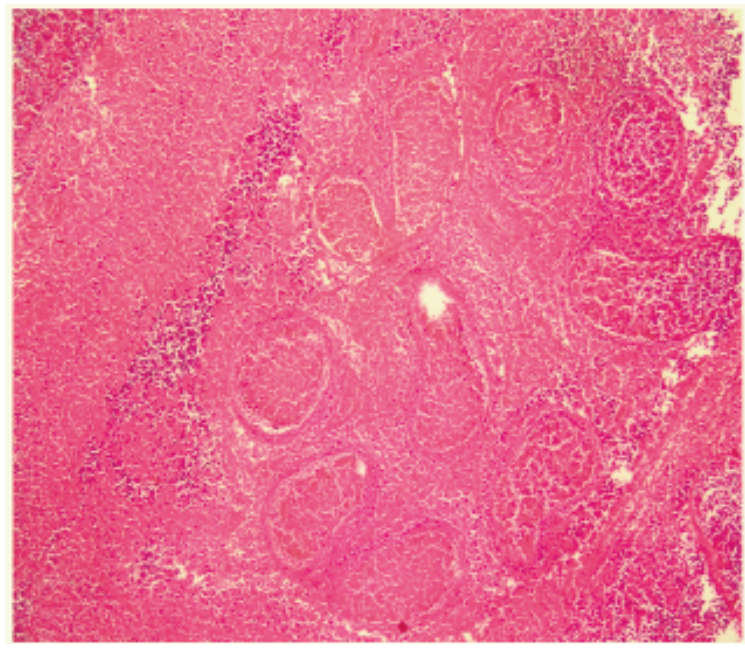

Fig. 1: Widespread necrosis and inflammation causing abscess formation and necrotic tubulus in testicular sections (haematoxylin and eosin $\mathrm{x} 40$ ).

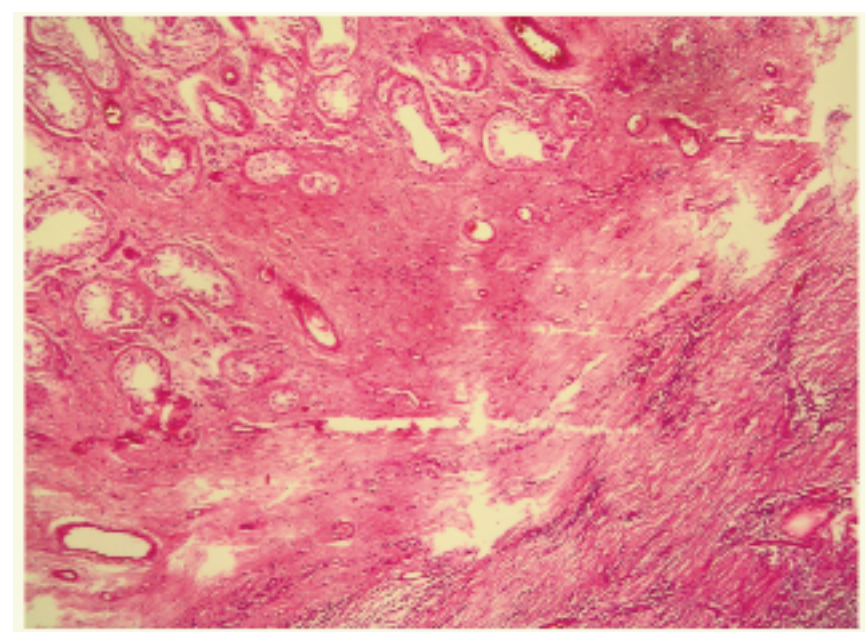

Fig. 2: Fibrotic and atrophic seminifereous tubules around the inflammation, necrosis and abscess (haematoxylin and eosin $\mathrm{x}$ 100).

referred to our centre, with the suspicion of brucella orchitis. Brucella Rose Bengal and serum agglutination tests (SAT) were performed and were all positive (the latter in a titre of 1/80). Blood culture was implemented using manufactured bottle of Becton Dickinson (BD) Bactec automated system (New Jersey, USA). After the cultivation in blood cultures, bacteriologic cultures were done on Mac Conkey's agar (Salubris, Istanbul, Turkey), blood agar (Salubris, Istanbul, Turkey) and chocolate agar (Salubris, Istanbul, Turkey) and incubated for seven days at $37^{\circ} \mathrm{C}$. The diagnosis was confirmed when Brucella melitensis was detected in the patient's blood culture. He was treated with $200 \mathrm{mg} /$ day doxycycline plus $600 \mathrm{mg}$ /day rifampicin orally for six weeks. After treatment, all complaints resolved.

Case 2: A 20-year old shepherd was admitted to a state hospital with a complaint of left testicular enlargement for

Table: Review of the brucella epididymo-orchitis cases

\begin{tabular}{rcccc}
\hline & $\begin{array}{c}\text { Navarro-Martinez } \\
\text { et al (5) }\end{array}$ & $\begin{array}{c}\text { Akinci } \\
\text { et al (16) }\end{array}$ & $\begin{array}{c}\text { Roushan } \\
\text { et al (4) }\end{array}$ & $\begin{array}{c}\text { Gul } \\
\text { et al (10) }\end{array}$ \\
\hline $\begin{array}{c}\text { Symptoms } \\
\text { Scrotal pain and }\end{array}$ & & & & \\
swelling & $100 \%$ & $94 \%$ & $47 \%$ & $100 \%$ \\
Fever & $88 \%$ & $53 \%$ & $47 \%$ & $100 \%$ \\
Sweating & $73 \%$ & $59 \%$ & $29 \%$ & $78,94 \%$ \\
Shivers & $63 \%$ & $35 \%$ & $29 \%$ & $100 \%$ \\
Treatment & & & & $100 \%$ \\
Dox+Rif & $17 \%$ & $58 \%$ & 0 & 0 \\
Dox+AG & $66 \%$ & $23 \%$ & $100 \%$ & 0 \\
Dox+Stm & $53 \%$ & $23 \%$ & 0 & $10,52 \%$ \\
Orchiectomy & $5 \%$ & $11 \%$ & $5 \%$ & \\
\hline
\end{tabular}

Dox $=$ doxycycline, Rif $=$ rifampicin, $\mathrm{AG}=$ aminoglicoside, $\mathrm{Stm}=$ sulfamethoxazole/trimethoprim 
two months. A fistula draining to the skin was found. $\mathrm{He}$ complained of a preceding period of episodic subfebrile temperature, night sweats and fatigue. The bacteriologic cultures of the pus from the fistula did not cultivate any bacteria. The patient underwent left radical inguinal orchiectomy because of the possibility of malignancy. However, multiple histologic sections of the testis revealed pronounced granulomatous inflammation marked by the presence of innumerable noncaseating granulomas. Rose Bengal test was positive and brucella SAT showed a titre of $1 / 320$. He was treated with rifampicin (600 mg/day) plus doxycycline $(200 \mathrm{mg} /$ day $)$.

\section{DISCUSSION}

Brucellosis may cause multisystem infection with moderate to severe complications. The gastrointestinal system is affected in $2 \%$ to $20 \%$, the musculoskeletal system in 20 $60 \%$ and the genitourinary tract in $2-20 \%$ of the cases. Brucellosis is especially common in Mediterranean countries as well as in Turkey $(2,3)$.

Brucella orchitis is diagnosed serologically, ultrasonographically and by the presence of symptoms, such as fever, testicular pain, enlargement and redness. A review from Iran revealed scrotal pain and swelling as the most prevelant symptoms of brucella orchitis. Fever, sweating, and arthralgia or arthritis occurred in 43 (84.3\%), 40 (78.4\%) and $25(47.1 \%)$ cases, respectively (4). Navarro-Martinez et al emphasized scrotal pain and swelling as well as fever (temperature, $38{ }^{\circ} \mathrm{C}$ ) as the most prevalent symptoms (5). Nevertheless, epididymo-orchitis may occur in the absence of systemic symptoms in endemic areas (6).

Both cases had most of these symptoms and were at risk because of occupational exposure. Brucella infection is usually acquired as a result of direct contact with infected animals or by consuming their fresh milk or cheese made from the milk.

The diagnosis of scrotal diseases is usually based on clinical evaluation and laboratory results. Brucella epididymo-orchitis can be distinguished from other acute nonspecific types by its gradual onset, longer duration, history of contact with animals, or ingestion of unpasteurized dairy products, typical undulant fever and normal urographic findings. The presumptive diagnosis of brucella orchitis can be made via serological testing. As in the index cases, brucella orchitis is mostly diagnosed by SAT. However, SAT titres may be low in chronic brucellosis. Rarely do patients with brucellosis have positive blood cultures but negative serological results. In these patients, radioimmunoassay and enzyme immunoassay techniques for brucella $\operatorname{IgG}$ and $\operatorname{IgM}$ may be used (7). Brucellacapt test (Vircell, Granada, Spain) is based on an immunocapture agglutination technique and offers a valuable alternative to the Coombs test. It shows similar sensitivity and specificity with the serologic tests but more rapidly detects brucellosis. However, chronic and relapsing forms of brucellosis are better detected by the
Coombs test (8). Overall, molecular assays have good potential in the investigation of patients with brucellosis. However, further standardization and optimization are necessary to determine reliability before they are used in routine laboratory investigations (9). In these cases, brucella can be insolated from blood culture, bone marrow aspirates and epididymal aspiration (10). Medical history, physical examination, ultrasonography and nuclear testicular scans are useful tests to help differentiate the aetiology of the acute scrotum. Ultrasonography plays an important role in the diagnosis, assessment and management of patients with brucella epididymo-orchitis (11). Ultrasonography is more useful in enabling the exclusion of the possibility of abscess or tumour than it is in helping to establish the primary clinical diagnosis. Usually it is not possible to rule out malignant disease, despite complete laboratory work-up and clinical examination.

The differential diagnosis of the acutely enlarged testis includes trauma, haematocele, testicular tumour or torsion of the testicle (12). The other aetiologic factors of an infiltrative process involving both the epididymis and the testis should include bacterial epididymo-orchitis, tuberculosis, sarcoidosis, lymphoma and leukaemia. In these cases, we could use magnetic resonance imaging (MRI) examination for the differential diagnosis (13). Brucella orchitis should be considered in a patient with epididymo-orchitis in endemic regions.

At present, a combination of antibiotics is the most adequate treatment. The mainstay of treatment of brucella orchitis is combinations of rifampicin, doxycycline, tetracycline, ciprofloxacin, cotrimoxazole and streptomycin for six weeks. These drugs have been found to be effective in $90 \%$ of cases. However, relapse rates are about $10 \%$. Relapse of brucellosis may manifest with an isolated testicular abscess and without systemic symptoms (6). The World Health Organization (WHO) recommends combination of $200 \mathrm{mg}$ doxycycline and $600 \mathrm{mg}$ rifampicin daily for four to six weeks. The patients in this report were treated as recommended by the WHO (15). Alternatively, streptomycin intramuscularly and tetracycline, with or without cotrimoxazole orally may be used in cases that do not respond to standard therapy (15). In some reports, orchiectomy was required in brucella epididymo-orchitis because of the difficulty in differentiation between benign and malignant diseases (16). At this stage, we suggest thorough laboratory evaluation for brucellosis. If it is positive, we recommend immediate and specific therapy with antibiotics specific for brucellosis. Nevertheless, if the laboratory tests for brucellosis are negative, orchiectomy seems a better approach. The Table summarizes the patients' data and treatment of the four reports reviewed $(4,5,10,16)$.

In conclusion, brucellosis should be considered as a differential diagnosis of testicular enlargement and masses, especially in endemic regions. Moreover, it is important to 
decide which medical therapy and/or surgical techniques will be performed, especially in young adults. We suggest that medical history, such as the patient's occupation and region of abode is very important in alerting physicians to brucella orchitis.

\section{REFERENCES}

1. Celenk MK, Ulug M, Ayaz C, Geyik MF, Hosoglu S. Brucellar epididymo-orchitis in southeastern part of Turkey: an 8-year experience. Braz J Infect Dis 2010; 14: 109-15.

2. Young EJ. Brucella species. In: Mandell GL, Bennett JE, Dolin R, eds. Principles and Practice of Infectious Diseases. $5^{\text {th }}$ ed, New York: Churchill-Livingstone; 2000: 2386-93.

3. Colak H, Usluer G, Karaguven B, Kose S, Ozgunes I. Seroepidemiologic screening for brucellosis in rural areas. Turk J Infect 1991; 5: $83-6$.

4. Roushan MR, Baiani M, Javanian M, Kasaeian AA. Brucellar epididymo-orchitis: review of 53 cases in Babol, northern Iran. Scand J Infect Dis 2009; 41: 440-4.

5. Navarro-Martínez A, Solera J, Corredoira J, Beato JL, Martínez-Alfaro E, Atiénzar M et al. Epididymo-orchitis due to Brucella mellitensis: a retrospective study of 59 patients. Clin Infect Dis 2001; 33: 2017-22.

6. Koçak İ, Dündar M, Çulhaci N, Ünsal A. Relapse of brucellosis simulating testis tumor. Int J Urol 2004; 11: 683-5.
7. Demirturk N, Karaaslan T, Samli M. Brucellosis: report of two cases with complications. T Klin J Microbiol-Infec 2003; 2: 17-20.

8. Casanova A, Ariza J, Rubio M, Masuet C, Díaz R. BrucellaCapt versus classical tests in the serological diagnosis and management of human brucellosis. Clin Vaccine Immunol 2009; 16: 844-51.

9. Araj GF. Update on laboratory diagnosis of human brucellosis. J Antimicrob Agents 2010; 36: 12-7.

10. Gul HC, Akyol I, Sen B, Adayener C, Haholu A. Epididymoorchitis due to Brucella melitensis: review of 19 patients. Urol Int 2009; 82: $158-61$.

11. Patel PJ, Kolawole TM, Sharma N, al-Fagih S. Sonographic findings in scrotal brucellosis. J Clin Ultrasound 1988; 16: 483-6.

12. Salata RA. Brucellosis. In: Goldman L, Bennet JC, eds. Cecil Textbook of Medicine. $21^{\text {st }}$ ed. Philadelphia: WB Saunders; 2000: 1717-9.

13. Tsili AC, Tsampoulas C, Giannakis D, Papastefanaki M, Tsiriopoulos I, Sofikitis $\mathrm{N}$ et al. Case report: tuberculous epididymo-orchitis: MRI findings. Br J Radiol 2008; 81: 166-9.

14. Corbel MJ, Elberg SS, Cosivi O, eds. Brucellosis in humans and animals. Geneva: World Health Organization; 2006. Available from: http://www.who.int/csr/resources/publications/Brucellosis.pdf

15. Al-Tawfiq JA. Brucella epididymo-orchitis: a consideration in endemic area. Int Braz J Urol 2006; 32: 313-5.

16. Akinci E, Bodur H, Cevik MA, Erbay A, Eren SS, Ziraman I et al. A complication of brucellosis: epididymo-orchitis. Int J Infect Dis 2006; 10: $171-7$. 